\title{
RANCANG BANGUN MESIN PENETAS TELUR OTOMATIS MENGGUNAKAN MIKROKONTROLER ARDUINO UNO
}

\author{
Mohamad Rizky Wirajaya \\ Prodi Teknik Elektro \\ Universitas Negeri Gorontalo \\ Gorontalo, Indonesia \\ *rizkywirajaya30@gmail.com
}

\author{
Syahrir Abdussamad \\ Prodi Teknik Elektro \\ Universitas Negeri Gorontalo \\ Gorontalo, Indonesia \\ syahrirabdussamad@yahoo.co.id
}

\author{
Iskandar Z. Nasibu \\ Prodi Teknik Elektro \\ Universitas Negeri Gorontalo \\ Gorontalo, Indonesia \\ zul.nasibu@ung.ac.id
}

\begin{abstract}
Abstrak-Proses penetasan terbagi dua yaitu proses penetasan alami (menggunakan indukan), dan proses penetasan buatan (menggunakan mesin tetas). Jika hanya mengandalkan penetasan alami persentase keberhasilan telur yang menetas hanya sekitar 50\% - 60\%. Kegagalan ini dapat disebabkan karena kondisi lingkungan yang tidak stabil dan dapat mengakibatkan embrio didalam telur tidak berkembang dengan sempurna. Untuk itu dibuatlah mesin penetas telur otomatis dengan pengontrolan suhu dan kelembaban yang dikontrol langsung oleh Arduino uno dengan menggunakan sensor DHT11 sebagai sensor utama dan RTC DS3231 sebagai counter waktu penetasan telur, dan waktu berputarnya telur serta LCD Keypad shield 16x2 sebagai penampil menu dan mode, dan juga sebagai input data suhu dan kelembaban pada menu custom. Tujuan dari penelitian ini agar dapat menetaskan telur dengan tingkat keberhasilan yang tinggi. Mesin penetas telur otomatis ini menggunakan lampu pijar sebagai penghasil suhu dan humidifier sebagai alat pelembab udara yang digunakan untuk mendapatkan kelembaban yang dibutuhkan telur yang dikontrol langsung oleh Arduino uno. Metode penelitian ini menggunakan metode perancangan dan metode eksperimen mesin penetas telur. Hasil penelitian ini adalah rancang bangun mesin penetas telur otomatis menggunakan mikrokontroler Arduino uno. Pada pengujian yang dilakukan dengan menggunakan telur ayam pada set point suhu : 37 - 38 ${ }^{\circ} \mathrm{C}$ dengan kelembaban yaitu $55-60 \%$, diperoleh hasil dengan persentase yaitu sekitar $98 \%$.
\end{abstract}

Kata Kunci-Mikrokontroller, sensor DHT11, RTC DS3231, humidifier, Suhu dan kelebaban

\section{Pendahuluan}

Reproduksi merupakan proses perkembang biakan untuk setiap makhluk hidup, termasuk unggas yang banyak di budidayakan sebagai hewan ternak di Indonesia. Semua unggas melakukan reproduksinya dengan cara bertelur. Setelah melalui proses perkawinan antara indukan jantan dan betina, selang waktu tertentu indukan betina akan mengeluarkan telur hasil pembuahannya.

Jumlah telur yang dihasilkan untuk setiap jenis unggas bervariasi. Ayam dapat menghasilkan 13-20 butir telur dalam sekali masa bertelur dimana seekor ayam dapat menghasilkan 1 butir telur dalam sehari. Berbeda dengan ayam, itik hanya dapat menghasilkan 2-3 butir telur per tiga hari. Secara alami, induk betina akan mengerami telurnya selama waktu tertentu hingga menetas menjadi anakan. Waktu yang dibutuhkan untuk mengerami telurnya berbedabeda untuk setiap jenis unggas. Lama penetasan telur ditempat pengeraman sangat tergantung dari besar kecilnya telur. Semakin besar ukuran telur biasanya semakin lama waktu yang dibutuhkan untuk mengerami telur hingga saat menetas menjadi anakan sebaliknya, semakin kecil ukuran telur maka akan semakin cepat pula waktu pengeraman yang dibutuhkan.

Setiap telur dari berbagai jenis unggas mempunyai lama waktu penetasan yang berbeda-beda. Telur ayam mempunyai lama penetasan normal selama 21 hari, untuk telur itik/bebek mempunyai lama penetasan selama 27 - 30 hari, sedangkan untuk entok mempunyai lama penetasan selama 35 - 40 hari.

Jika hanya mengandalkan pengeraman alami persentase keberhasilan telur yang menetas hanya sekitar 50\%-60\%. Kegagalan ini dapat disebabkan karena kondisi lingkungan yang tidak stabil dan dapat mengakibatkan embrio didalam telur tidak berkembang dengan sempurna. Dalam usaha peternakan, penetasan telur merupakan hal yang sangat penting untuk kelangsungan usaha.(Wakhid, 2017)

Apabila proses penetasan alami yaitu penetasan dengan menggunakan indukan mengalami kendala yang disebabkan oleh indukannya sendiri dan lingkungan yang tidak mendukung, dapat mengakibatkan kerugian bagi peternak karena resiko telur yang gagal menjadi besar. Karena itu perlu adanya inovasi untuk membantu penetasan telur agar resiko telur yang gagal dikarenakan faktor indukan dan lingkungan menjadi kecil.

Pengalaman peneliti sebagai peternak ayam, biasanya indukan yang baru pertama kali mengeram akan sering keluar dari tempat pengeraman yang dapat mengakibatkan telur tidak mendapatkan suhu yang dibutuhkan dan dapat mengakibatkan embrio pada telur tidak dapat berkembang dengan baik yang dapat memperbesar kegagalan dalam 
menetas, dan untuk indukan yang sudah terlalu tua biasanya akan meninggalkan telurnya dan tidak akan dierami lagi.

Mesin penetas yang sekarang banyak digunakan oleh para peternak unggas, biasanya menggunakan mesin penetas yang masih melakukan pengaturan suhu dan kelembapan untuk setiap jenis telur unggas yang akan di tetaskan. Dengan mempertimbangkan kondisi tersebut maka dapat dilakukan penelitian dengan cara dibuatnya rancangan alat mesin.

Tujuan penelitian ini adalah merancang dan membuat mesin penetas telur otomatis menggunakan arduino uno.

\section{KAJIAN PUSTAKA}

Penelitian yang dilakukan oleh Ridho Wahyudi yang meneliti pada tahun 2017 dengan judul: Pembuatan Mesin Penetas Telur Otomatis. Kesimpulan dari penelitian ini adalah, mesin penetas menggunakan thermostat yang memutuskan arus listrik yang masuk ke kipas dan lampu ketika suhu di dalam ruangan akan mencapai $38^{\circ} \mathrm{C}$ dan menghubungkan kembali arus listrik ke kipas dan lampu pada saat suhu ruangan akan mencapai $37,5^{\circ} \mathrm{C}$. Suhu yang dibutuhkan oleh telur adalah $38^{\circ} \mathrm{C}$ dan kelembaban dari hari 1 sampai hari ke 18 adalah $55 \%$ sampai $60 \%$ sedangkan dari hari ke 19 sampai hari ke 21 adalah $70 \%$. Kekurangan dari penelitian ini ialah kelembaban yang tidak bisa diatur karena masih menggunakan bak air yang di letakan dibawah rak telur. Dengan tingkat keberhasilan hampir mencapai $100 \%$.

Penelitian yang dilakukan oleh Imam Nurhadi \& Eru Puspita, yang meneliti pada tahun 2009 dengan judul: Rancang Bangun Mesin Penetas Telur Otomatis Berbasis Mikrokontroler Atmega8 Menggunakan Sensor SHT11. Penelitian ini mempunyai tingkat keberhasilan diatas $75 \%$, dengan menggunakan Standar untuk suhu dalam inkubator "penetasan" adalah $38^{\circ} \mathrm{C}-39^{\circ} \mathrm{C}$ dengan memperhatikan kelembaban menggunakan Sensor SHT11. Standar untuk kelembaban relatif (relatif humidity) untuk mesin inkubator "penetas" atau periode 18 hari pertama harus dijaga pada 50-55 \%. Dan pada hari ke 19-21 sebelum penetasan, kelembaban udara harus dinaikkan menjadi 60-65\%. Kekurangan dari penelitian ini ialah kelembaban yang tidak bisa diatur karena masih menggunakan bak air yang di letakan dibawah rak telur.

Penelitian yang dilakukan oleh Yudhi Gunardi, yang meneliti pada tahun 2012 dengan judul : Perancangan dan Pembuatan Penetas Telur Berbasis Arduino Dumilanove. Kesimpulan penelitian ini adalah perancangan alat ini berbasis Arduino Dumilanove menggunakan sensor suhu IC LM35. Pengaturan suhu dibuat set point $38^{\circ} \mathrm{C}$, jika melebihi panasnya $>38^{\circ} \mathrm{C}$ maka kipas akan hidup untuk menstabilkan suhu menjadi $38^{\circ} \mathrm{C}$. Kekurangan dari penelitian ini ialah kelembaban yang tidak bisa diatur karena masih menggunakan bak air yang di letakan dibawah rak telur. Penelitian ini mempunyai tingkat keberhasilan yang sama seperti sebelumnya yaitu dengan tingkat keberhasilan diatas $50 \%$.

Setelah melihat hasil penelitian sebelumnya, penelitian yang dilakukan memiliki kelebihan yakni menggunakan sensor DHT11 sebagai sensor utama, RTC DS3231 sebagai Counter waktu penetesan telur dan waktu berputarnya telur, dengan pengontrol utama adalah mikrokontroler arduino uno [5]. Pengujian mesin penetas telur otomatis ini menggunakan pengujian 17 butir telur ayam yang ditetaskan, set point suhu 37-38 ${ }^{\circ} \mathrm{C}$ dengan kelembaban yaitu $55-60 \%$. Dalam pengujian ini terdapat 3 telur yang gagal dikarenakan tidak memiliki embrio didalamnya yang berarti telur tersebut tidak dapat ditetaskan oleh mesin tetas maupun oleh indukan. Sisanya 1 telur pada hari ke 20 saat cangkang telur sudah mulai menetas (berlubang), semut semut kecil masuk pada lubang kecil tersebut dang menggigit anak ayam didalamnya yang mengakibatkan anak ayam tersebut mati. Berarti tingkat keberhasilan mesin penetas telur ini hampir mencapai 100 persen, yaitu sekitar $98 \%$ diluar dari 3 telur yang tidak memiliki embrio tersebut.

\section{METODE}

Metode penelitian ini menggunakan metode perancangan dan metode eksperimen mesin penetas telur dengan tingkat keberhasilan yang tinggi dengan menggunakan tahapan untuk mempermudah dan memperjelas arah penelitian yaitu, perencanaan alat, perancangan, pengujian alat, kemudian hasil dan pembahasan. Seperti pada Gambar 1.

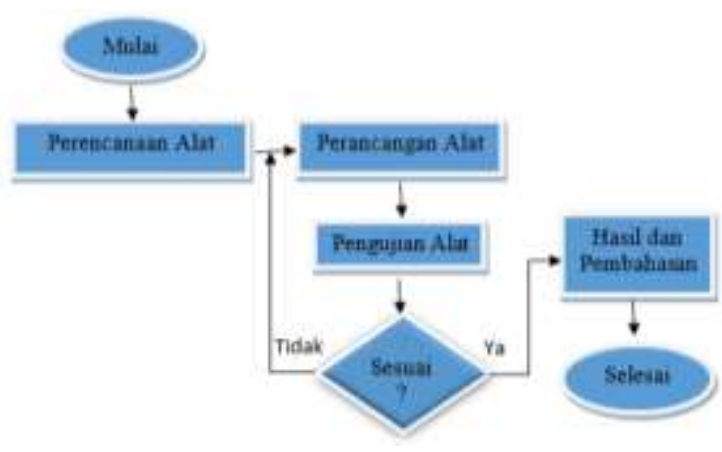

Gambar 1 Diagram alir tahapan penelitian

Mesin penetas telur ini dilengkapi dengan sensor suhu dan kelembaban sebagai sensor utama dan Humidifier sebagai penghasil kelembaban, deteksi suhu dan kelembaban tersebut akan diolah oleh Arduino Uno. Secara keseluruhan sistem dapat dilihat pada Gambar 2.

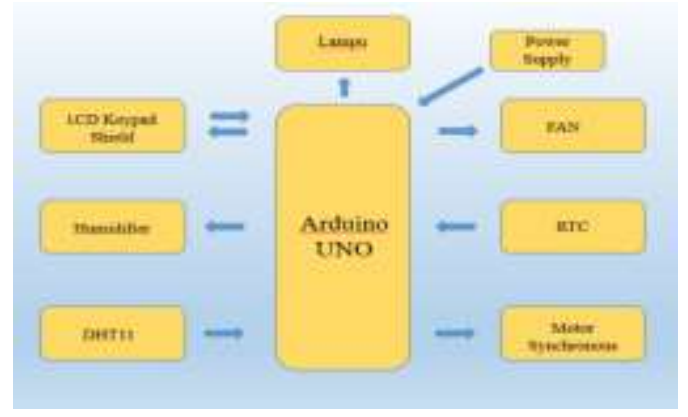

Gambar 2 Digram blok rancangan mesin penetas telur otomatis

Rancangan alat ini bekerja dengan suhu dan kelembaban sebagai parameter utama dan mempunyai 2 mode penetasan yaitu mode Chicken Egg dan mode Duck Egg dengan mode tambahan yaitu mode Custom yang berfungsi untuk menetaskan teluru selain telur ayam dan bebek/itik.

1) Perancangan perangkat keras (hardware) 
Perancangan perangkat keras meliputi pengujian masingmasing komponen yang akan digunakan mulai dari sensor, Arduino Uno, RTC, LCD keypad shield, humidifier, dll

2) Perancangan perangkat lunak (software)

Pada bagian ini, perangkat lunak yang dimaksud adalah program yang akan dimasukkan pada Arduino uno melalui komputer. Program dibuat dengan bahasa C melalui software Arduino IDE (integrated development environment) berdasarkan alur kerja rancangan alat secara berurutan.

\section{HASIL DAN PEMBAHASAN}

\section{Hasil Rancangan Alat}

Setelah melakukan pengujian dari masing-masing alat atau komponen, selanjutnya melakukan pengujian alat secara keseluruhan yang berupa input, proses, dan output yang digabungkan secara keseluruhan sehingga menjadi kesatuan mesin penetas telur otomatis. Pada saat alat mulai dihidupkan, tampilan awal yang akan muncul pada LCD adalah nilai pembacaan suhu dan kelembaban didalam mesin tetas dan tampilan masuk ke menu. Berikut Gambar 3 dan 4 yang menunjukan keseluruhan dari rancangan alat.

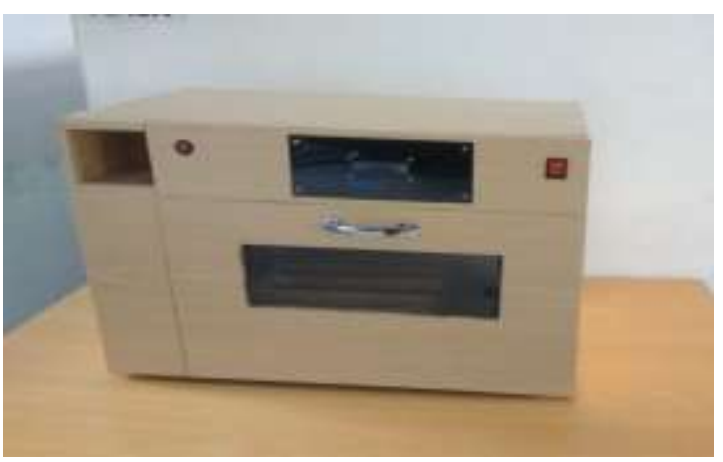

Gambar 3 Rancangan keseluruhan rancangan alat

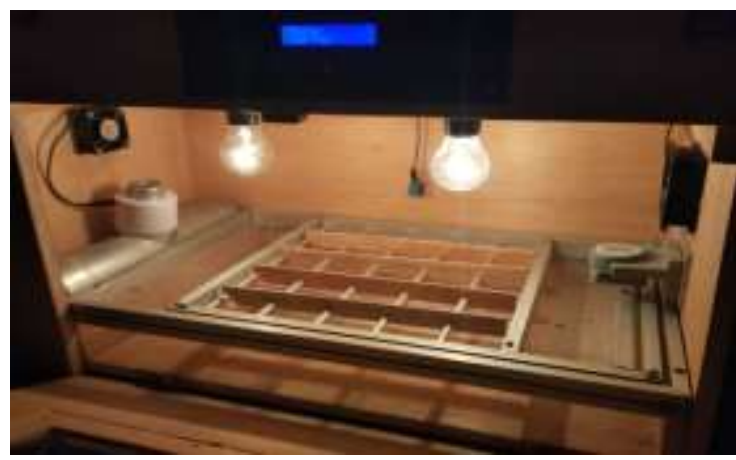

Gambar 4 Tampilan bagian dalam alat

Gambar 4 menunjukan bentuk keseluruhan dari rancangan alat dimana didalamnya terdapat sistem mikrokontroler, sensor DHT11, humidifier, motor synchronous, power supply adaptor $5 \mathrm{~V}$, tabung air, dan rak telur.

\section{Hasil Pengujian Alat}

Setelah mengetahui fungsi dari masing-masing menu, selanjutnya melakukan pengujian alat secara keseluruhan yang berupa input, proses, dan output yang digabungkan secara keseluruhan sehingga menjadi kesatuan mesin penetas telur otomatis dengan menggunakan telur ayam kampung.

Pada saat pertama kali alat dihidupkan, tampilan pertama yang akan muncul seperti pada LCD Gambar 5. Pengujian ini menggunakan telur ayam kampung sebagai uji coba dengan memilih mode Chicken Egg.

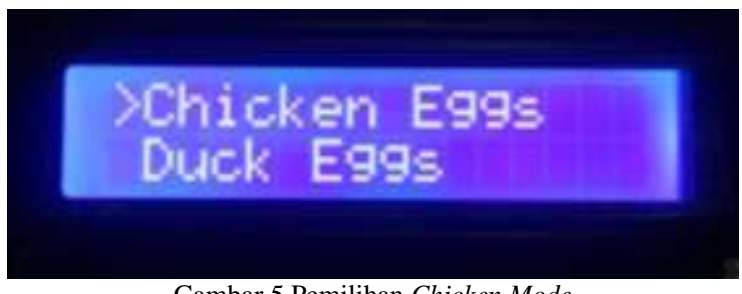

Setelah memillih Chicken Egg maka akan kembali ke tampilan awal, kemudian pada tampilan awal akan muncul notifikasi day dimana notifikasi tersebut befungsi sebagai pemberitahuan telah berapa lama hari terlewati, dan akan hilang setelah mencapai target penetasan sesuai data penetasan telur, seperti pada Gambar 6.

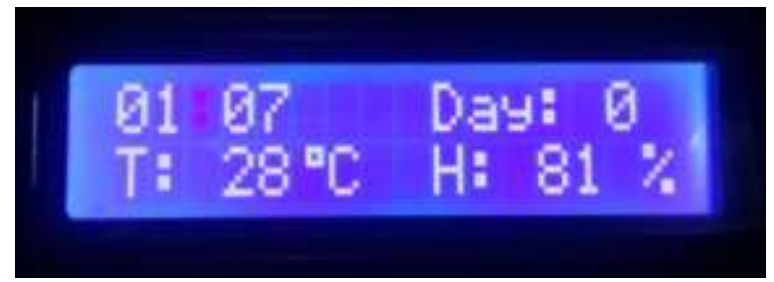

Gambar 6 Tampilan awal LCD dengan notifikasi day

Kemudian pada tampilan kedua pada LCD pada barisan pertama akan muncul status mode berdasarkan mode yang dipilih, contoh kita memilih Chicken Egg, maka pada tampilan kedua baris pertama akan muncul kalimat mode chicken, Seperti pada Gambar 7.

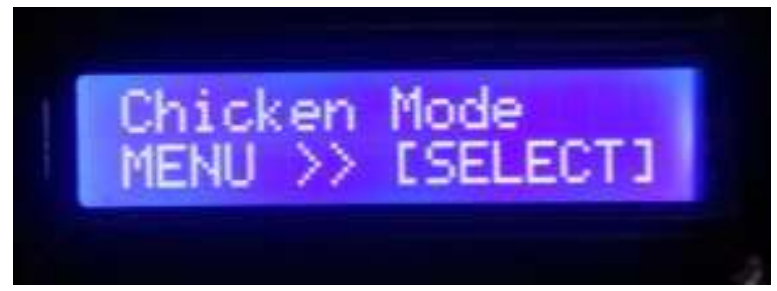

Gambar 7 Tampilan kedua LCD dengan Mode Chicken

Setelah memasukan telur dan telah memilih mode berdasarkan jenis telur yang dimasukkan maka proses penetasan dimulai. Pada penetasan ini menggunakan telur ayam sebagai pengujian alat apakah alat ini berhasil. Pengujian telur ayam dapat dilihat pada Gambar 8. 


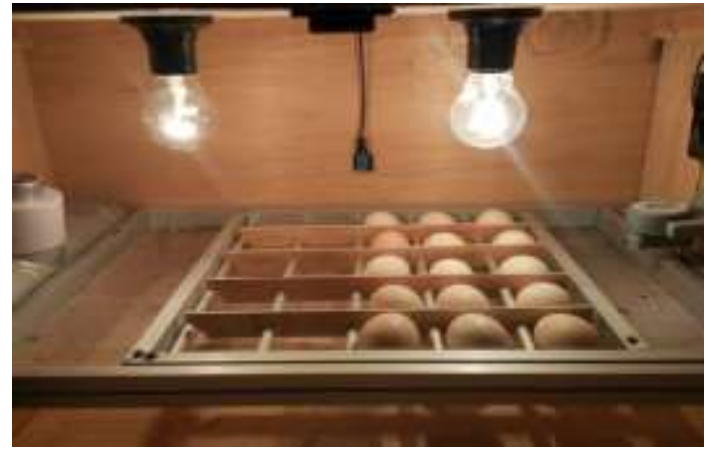

Gambar 8. Proses pengujian penetasan telur ayam

Pada saat telah memilih mode penetasan telur ayam, maka fungsi setter aktif. Fungsi setter ialah fungsi dimana telur akan mulai memutar (Roll) setelah 2 hari setelah pemilihan mode atau mulai memutar pada saat notifikasi hari menunjukan hari ketiga. Saat proses penetasan, pada hari saat memasukan telur sampai hari ketiga telur belum mengalami perubahan. Perubahan telur dapat diketahui dengan cara melihat isi telur menggunakan senter atau sumber cahaya lainnya yang mampu menembus cangkang telur. Proses melihar isi telur pada hari 3 dapat dilihat pada Gambar 9.

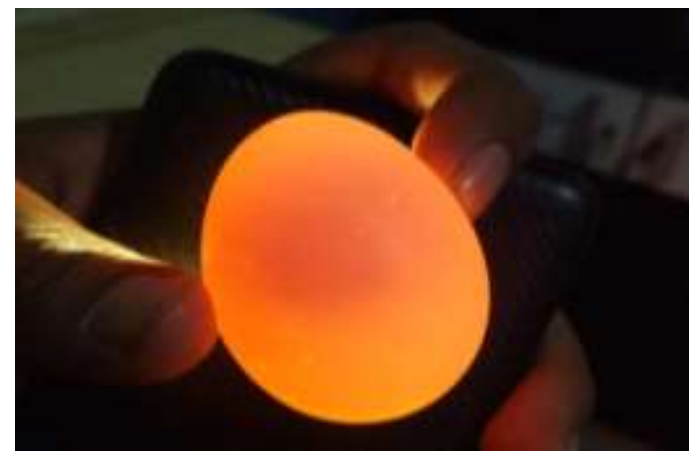

Gambar 9. Telur hari 1 - hari 3

Setelah hari 4 telur mulai mengalami perubahan yaitu, isi telur terlihat seperti mulai berakar. Perubahan telur dapat dilihat pada Gambar 10.

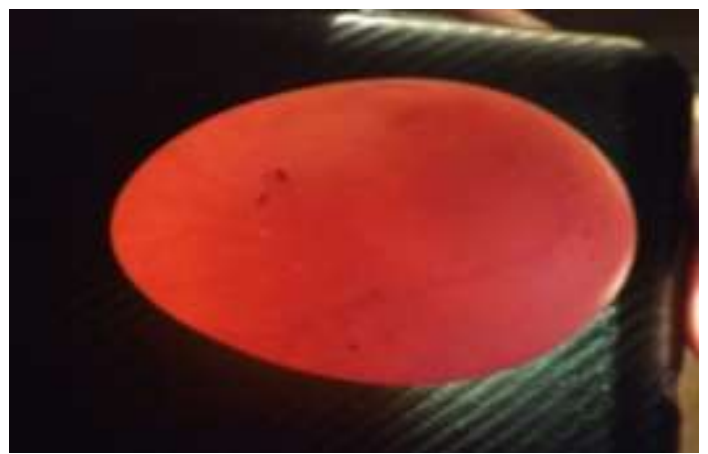

Gambar 10. Telur hari ke 4

Kemudian pada hari ke 5 dan hari ke 6 , telur belum mengalami perubahan. Setelah hari ke 7 telur mulai terlihat mengalami perubahan. Perubahan telur dapat dilihat pada Gambar 11.

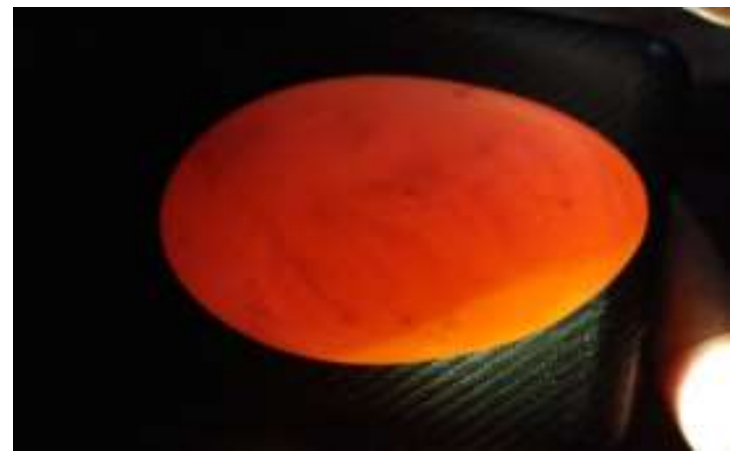

Gambar 11. Telur hari ke 7

Pada hari ke 8 perubahan yang terjadi ialah pada telur mulai terlihat gelap. Perubahan telur dapat dilihat pada Gambar 12.

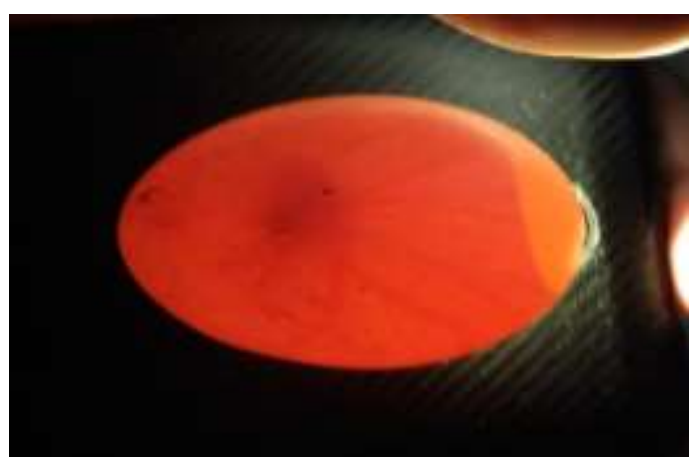

Gambar 12. Telur hari ke 8

Hari ke 9 dan hari ke 10 perkembangan telur tidak terlihat, setelah hari ke 11 bayangan hitam pada telur mulai terlihat banyak. Perubahan telur dapat dilihat pada Gambar 13.

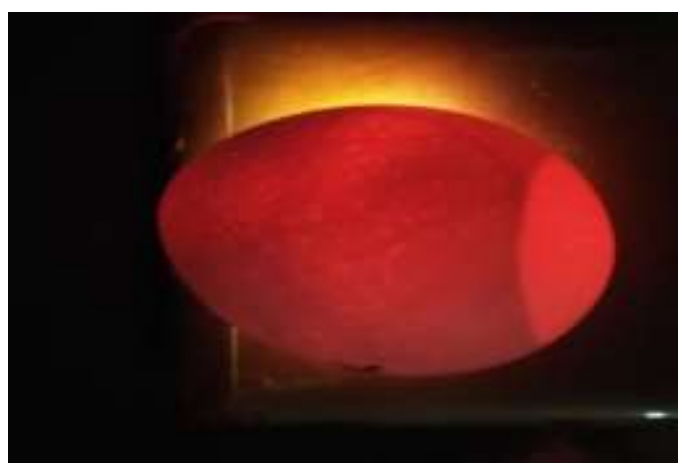

Gambar 13. Telur hari ke 11

Hari ke 12 perkembangan telur tidak terlihat sampai hari ke 13 barulah perkembangan telur terlihat tetapi tidak terlalu banyak perubahan. Perubahan telur dapat dilihat pada Gambar 14. 


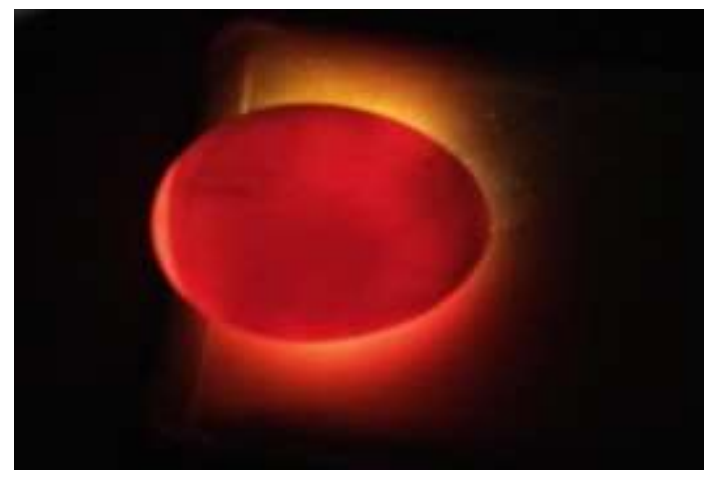

Gambar 14. Telur hari ke 13

Hari ke 14 sampai hari ke 15 bayangan didalam telur mulai menutupi cahaya senter yang digunakan untuk melihat perubahan telur. Perubahan telur dapat dilihat pada Gambar 15.

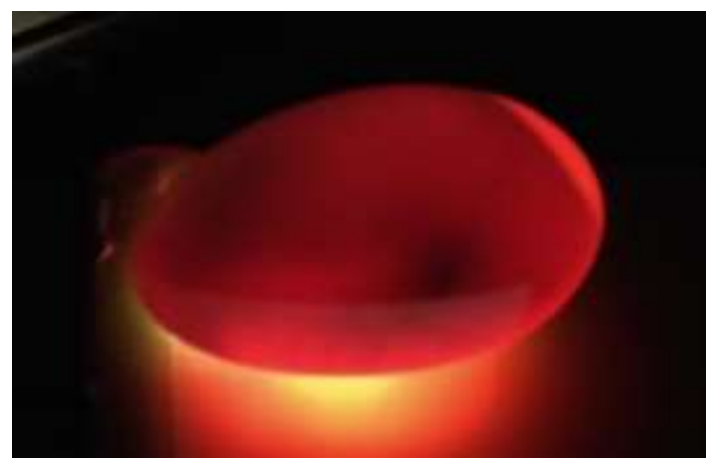

Gambar 15. Telur hari ke 14-15

Hari ke 16 sampai hari ke 18 cahaya senter sudah tidak dapat menembus telur yang artinya perkembangan ayam didalam telur sudah mulai sempurna, tinggal menunggu waktu menetas, seperti pada Gambar 16.

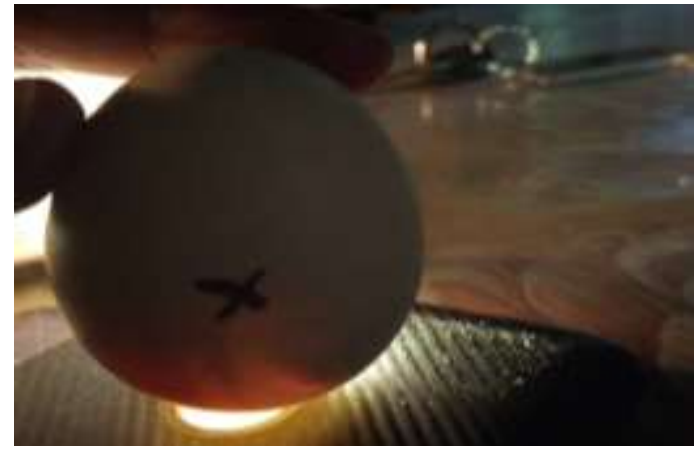

Gambar 16. Telur hari ke 16-18

Setelah hari ke 18 fungsi hatcher aktif. Hatcher ialah waktu dimana telur berhenti berputar sampai waktu penetasan. Setelah hari ke 20 telur mulai pecah, seperti pada Gambar 17.

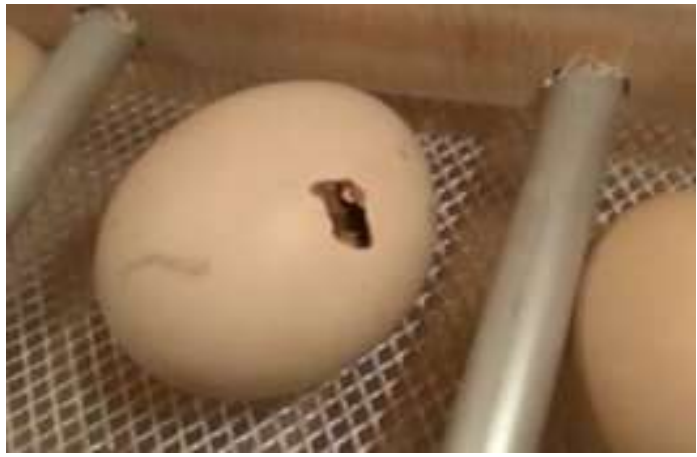

Gambar 17. Telur hari ke 20

Telur yang sudah mulai pecah seperti pada Gambar 17 masih memerlukan waktu satu hari untuk bisa menetas sepenuhnya agar ayam dalam telur dapat keluar dan mengeringkan bulu halus ayam. Jadi pada hari ke 21 telur akan menetas sepenuhnya, seperti pada Gambar 18.

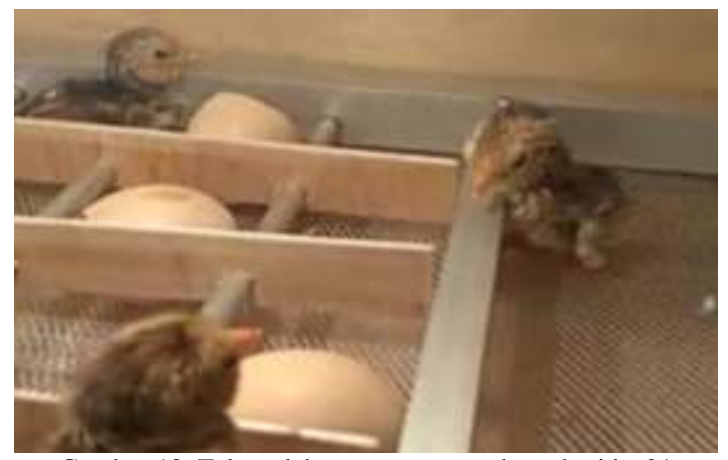

Gambar 18. Telur telah menetas sepenuhnya hari ke 21

Setelah hari ke 21 tampilan LCD akan kembali normal dan fungsi penetasan yaitu mode penetasan, pemutar telur, fungsi setter dan hatcher akan off. Akan tetapi sistem pembacaan suhu dan kelembaban masih akan tetap berjalan karena setiap telur memiliki masa penetasan yang berbeda (tidak menetas sekaligus).

\section{Pembahasan Standar Penetasan Unggas}

Berdasarkan data dari hasil wawancara dengan peternak rumahan dan dari media lainnya seperti buku dan sebagainya, setiap unggas memiliki data penetasan yang berbeda, data penetasan tersebut yang nantinya akan menjadi batas ukur dari mesin penetas telur otomatis ini.

Setelah mengetahui data penetasan dari telur yang akan ditetaskan maka proses penetasan dapat dilakukan. Data penetasan tersebut meliputi, suhu (Temperature), kelembaban (Humidity), waktu putaran telur (Roll), dan lama waktu penetasan telur (Day). Data penetasan dari beberapa jenis telur dapat dilihat pada Tabel I. 
TABEL I. DATA PENETASAN BEBERAPA JENIS TELUR

\begin{tabular}{|c|c|c|c|c|}
\hline Jenis Telur & $\begin{array}{c}\text { Suhu } \\
(\mathbf{} \mathbf{C})\end{array}$ & $\begin{array}{c}\text { Kelembabab } \\
\mathbf{( \% )}\end{array}$ & $\begin{array}{c}\text { Waktu } \\
\text { Putara }(\mathbf{h} / \mathbf{r})\end{array}$ & $\begin{array}{c}\text { Lama } \\
\text { Penetasan }\end{array}$ \\
\hline $\begin{array}{c}\text { Ayam } \\
\text { Kampung }\end{array}$ & $37-39$ & $55-60$ & 3 & 21 Hari \\
\hline $\begin{array}{c}\text { Ayam } \\
\text { Bangkok }\end{array}$ & $37-39$ & $55-60$ & 3 & 21 Hari \\
\hline $\begin{array}{c}\text { Ayam } \\
\text { Aduan }\end{array}$ & $37-39$ & $55-60$ & 3 & 21 Hari \\
\hline Bebek/Itik & $38-39$ & $75-85$ & 5 & 30 Hari \\
\hline Entok & $38-39$ & $75-85$ & 5 & 35 Hari \\
\hline Puyuh & $37-39$ & $60-65$ & 3 & 17 Hari \\
\hline Merpati & $37-39$ & $50-60$ & 3 & 18 Hari \\
\hline
\end{tabular}

Selain telur ayam dan bebek/itik yang memiliki mode sendiri pada menu mesin tetas, data penetasan pada tabel I sangatlah penting jika ingin menetasakan telur lain. Selain Chicken mode untuk ayam dan Duck mode untuk bebek/itik, kita dapat menggunakan Custom mode pada menu Custom. Menu Custom digunakan untuk menetaskan telur selain telur ayam dan telur bebek/itik, yaitu dengan cara memasukan data penetasan pada menu custom. Maka dari itu menu custom lah yang akan menjadi solusi dari telur yang lain.

\section{KESIMPULAN}

1. Rancangan Mesin Penetas Telur Otomatis Menggunakan Mikrokontroler Arduino Uno telah berhasil dibuat dengan 2 mode jenis telur ayam dan telur bebek/itik dengan tambahan mode Custom. Hasil rancangan menggunakan alat pelembab udara yang digunakan untuk mendapatkan kelembaban yang dibutuhkan telur yang dikontrol langsung oleh Arduino Uno dengan menggunakan sensor DHT11. Mode Chicken Egg menggunakan set point suhu : $37-38{ }^{\circ} \mathrm{C}$ dengan kelembaban yaitu 55-60\%. Mode Duck Egg menggunakan set point suhu : $38-39{ }^{\circ} \mathrm{C}$ dengan kelembaban yaitu $75-85 \%$. Custom mode digunakan untuk jenis telur selain telur ayam dan telur bebek/itik, agar dapat digunakan untuk semua jenis telur unggas lainnya, dengan menyesuaikan rak telur sesuai ukuran telur yang akan ditetaskan.

2. Mesin penetas telur otomatis dengan pengujian 17 butir telur ayam yang ditetaskan, 3 telur gagal dikarenakan tidak memiliki embrio didalamnya yang berarti telur tersebut tidak dapat ditetaskan oleh mesin tetas maupun oleh indukan. Dan 1 telur sisanya pada hari ke 20 pada saat cangkang telur sudah mulai menetas (berlubang), semut - semut kecil masuk pada lubang kecil tersebut dang menggigit anak ayam didalamnya yang mengakibatkan anak ayam tersebut mati. Yang berarti tingkat keberhasilan mesin penetas telur ini hampir mencapai 100 persen, yaitu sekitar 98\% diluar dari 3 telur yang tidak memiliki embrio tersebut..

\section{REFFERENSI}

[1] Gunardi, Y. (2012). Perancangan dan Pembuatan Penetas Telur Berbasis Arduino Dumilanove. Program Studi Teknik Elektro, Fakultas Teknik, Universitas Mercu Buana. Jakarta.

[2] (http://digilib.mercubuana.ac.id/manager/t!@file_artik el_abstrak/Isi_Artikel_431374599154. Diakses 10 Agustus 2018).

[3] Kadir, A. (2012). Panduan Praktis Memperlajari Aplikasi Mikrokontroler Dan Pemrogramannya Menggunakan Arduino. Yogyakarta: Andi.

[4] Nurhadi, I., \& Puspita, E. (2009). Rancang Bangun Mesin Penetas Telur Omtomatis Berbasis Mikrokontroler ATMega8 Menggunakan Sensor SHT 11. Surabaya.

[5] Usman R. F, Ridwan W, Nasibu Z. I, (2019). Sistem Peringatan Dini Bencana Banjir Berbasis Mikrokontroler Arduino. Jambura Journal of Electrical and Electronics Engineering. Volume 1 Nomor 1 Januari 2019. hal 2

[6] Wahyudi, R. (2017). Pembuatan mesin penetas telur otomatis. . Jurusan Teknik Mesin, Politeknik Negeri Padang. Padang.

[7] (http://repo.polinpdg.ac.id/1283/1/Ridho_Wahyudi_ME -D3. Diakses 27 Agustus 2018).

[8] Wakhid, A. (2017). Membuat Sendiri Mesin Tetas Praktis. Jakarta: AgroMedia Pustaka.

[9] Winoto, A. (2010). Mikrokontroler AVR ATmega8/32/16/8535 dan Pemrogramannya Dengan Bahasa C Pada WinAVR. Bandung: Informatika. 